\title{
Research on Stone Materials and the Thermal Environment of Dwellings
}

\author{
Liping Li, Shuai Fan \\ Department of Architecture, Faculty of Architecture and City Planning, \\ Kunming University of Science and Technology, Kunming , China \\ Ilping402@163.com, fs1204@sina.com
}

Keywords: Dwellings; stone materials; temperature; test and analysis

\begin{abstract}
Under the circumstances of backward production tools and technologies, varied and graceful local buildings are built by using the local materials with the wisdom of the working people. The article analyzed stone dwellings in Yuhu village in Lijiang Yunnan Province as cases. Based on the field testing and analysis of the stone dwelling in Lijiang, and more specifically, the indoor temperature of the dwellings with stone walls as well as the surface temperature of building envelope were tested and comparatively analyzed. The test results reveal that the maximum and the minimum of the indoor air temperature is $5.1^{\circ} \mathrm{C}$ and $8.4{ }^{\circ} \mathrm{C}$ higher than one of the outdoor temperature, an amplitude of the indoor air temperature is $3.6^{\circ} \mathrm{C}$ lower than one of the outdoor temperature. The test results show the current situations and features of indoor temperature changes of these dwellings of stone materials, the heat-insulation performance and heat stability of stone wall, which may provide a basis for improving the thermal environment of Naxi nationality dwellings.
\end{abstract}

\section{Introduction}

Under the circumstances of backward production tools and technologies, varied and graceful local buildings are built by using the local materials with the wisdom of the working people. Under the local climate and environment, unique building types that are harmonious with the natural environment are built. In these buildings, there are many "green” construction ideas and technologies. In the previous researches on local buildings, it is analyzed mainly from the formation of ancient settlement, the types of buildings, landscape and the manifestation of buildings as the carrier of culture, etc. As for the survey on the local buildings of the Naxi nationality in Yuhu village this time, these dwellings are analyzed and researched mainly from building technology and the indoor thermal environment testing of building, etc.

Yuhu village is located under footing of Jade Dragon Snow Mountain(Yulong Mountain), fifteen kilometers from Lijing County Town, the last and the highest village at northwestward in Lijing Basin, 2730 meters of elevation at village administration, belongs to the northern temperate zone according to the Design standard for energy efficiency of civil buildings(DBJ53/T-39-2011) [1] , belongs to climate region (VA) according to the Standard of Climatic Regionalization for Architecture (GB50178-93) [2] and Thermal Design Code for Civil Building (GB 50176-93) [3]. The air minimum temperature is $-5^{\circ} \mathrm{C}$ in winter . This area features particularly hot and wet, as shown in Fig.1.In order to understand the current situations of indoor thermal environment and saving-energy of stone dwellings in Yuhu of Lijiang in Yunnan Province, we tested on such parameters as indoor temperature and the surface temperature of building envelope in 1999, and found out the changes and features of the test parameters through comparative analysis, which provides a necessary actual measurement basis for improving the comfort of indoor thermal environment of stone dwellings in winter. 


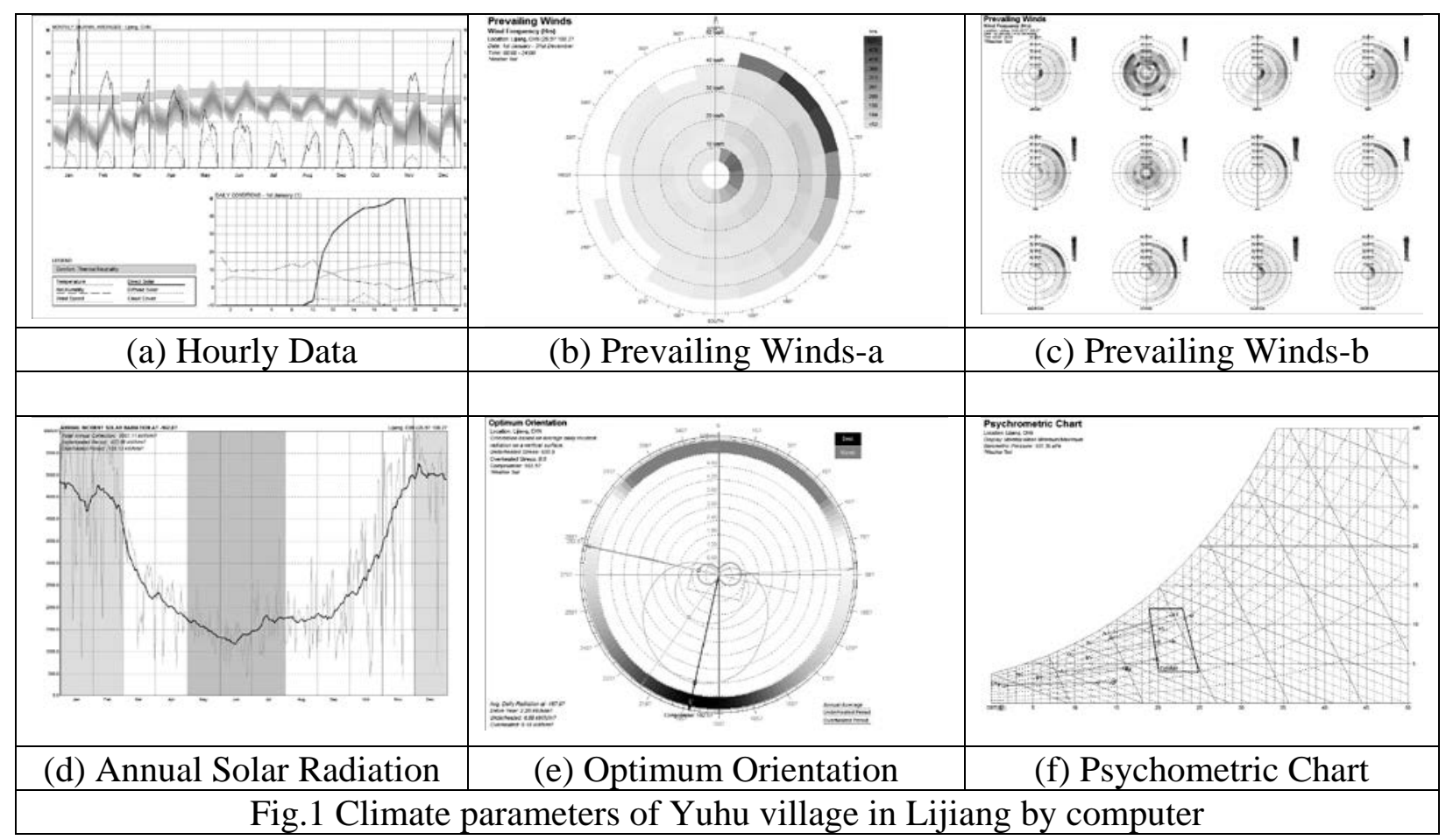

\section{Basic Information on Buildings}

Yuhu village is located under footing of Jade Dragon Snow Mountain, fifteen kilometers from Lijing County Town, the last and the highest village at northwestward in Lijing Basin, 2730 meters of elevation at village administration. The Maxi nationality calls the village as "en-nu-ken" that mean "under foot of silvery stone shore", where is edge zone of the under footing of Jade Dragon Snow Mountain and high mountain land area, climate of cold temperate zone of mountain region, the soil type with brown soil and meadow soil and so on. The plantation contains a great quantity of sand and stone and is poor food productivity. There is a Yu-lake at north of village. Yu-lake could be not dry up in the four seasons and be built as artificial lake by minority headman of Mu family, where there are meadow of high mountain, wild flowers, wild animal, mountain region landscape. It is said there are forty-one high mountain azaleas that grow to tracts of forest in Sit-Deer level ground, how beautiful it is!

The dwelling of Yuhu village are tile-roofed houses with stone and wood structure. The dwelling is as shown in Fig.2. From picture, the space scale and courtyard size of the dwellings are smaller than
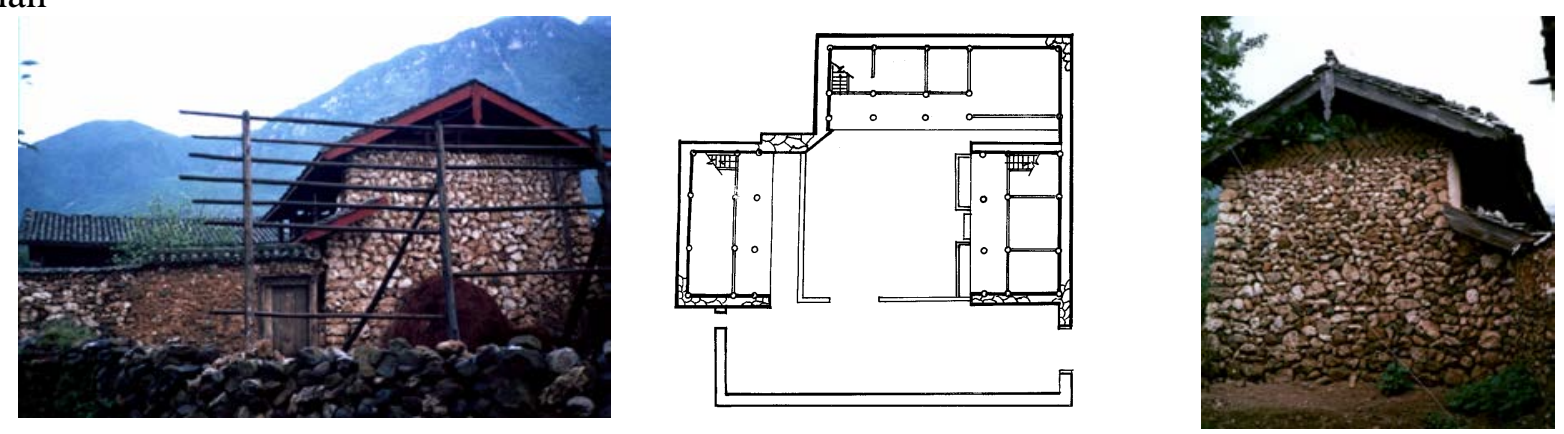

Fig.2 The stone dwellings of Yuhu village

the one in basin, with 2.35 meters of first floor height and 2.30 meters of second floor height, for the reason that village near Jade Dragon Snow Mountain, elevation higher than Lijing ancient city, 
bigger wind in winter and lower temperature. The dwellings are suit to local geography climate and conditions, for that combination with small space scale and tight link is make for reducing heat dissipation and energy saving.

Here dwellings are very unusual houses for people or animal to live in, built by a amount of white rubble and black rubble. They are coordinate and fused together with surrounding high mountains, trees and rills, like nature object grow up from mountain region. There rubbles were nature materials that were excavated from mountains distant to about two kilometers and no payment. White stone is soft when excavated then change to hard under the sunshine. Black stone is hard and smooth. Local people use these stone for building without more cost and long-distance transport, reducing building cost and saving construction time. At the same time these stone absorb sun heat in daytime and keep heat out the indoor, and let out heat in night keep heat into building, so that sun energy be used effectively.

In the other side, these nature materials come from the nature and could be circulate used when old dwellings demolished, that could be not give rise to environmental disruption. These stone are green building materials and sustainable development.

\section{Test Methods, Test Instruments and Layout of Testing Points}

The tests were carried out continuously for $24 \mathrm{~h}$ in winter, with an interval of $1 \mathrm{~h}$. To reduce the measurement error, all test instruments had been calibrated prior to the test. The tests were carried out in winter, during which this area featured cold night and strong solar radiation in the daytime outdoors, and it is at the place with an elevation of $1.5 \mathrm{~m}$.

Raytek RayngerST infrared thermometer manufactured by America was used for measuring the temperature, with the measurement ranging from $-32^{\circ} \mathrm{C}$ to $535^{\circ} \mathrm{C}$ and a precision of $0.1^{\circ} \mathrm{C}$, which may be used for measuring the surface temperature of the ground, wall and roof. Moreover, UNITEC MCT-111 portable digital thermometer manufactured by Unite Technique Development Company was adopted for measuring the indoor and outdoor air temperature, with the measurement ranging from $-200^{\circ} \mathrm{C}$ to $400^{\circ} \mathrm{C}$ and a precision of $0.1^{\circ} \mathrm{C}$, which has 0.1 resolution within the scope of $-200^{\circ} \mathrm{C}$ $-200^{\circ} \mathrm{C}$.

Layout of testing points: according to the situations of stone dwellings, the testing points were arranged at the middle of the rooms about $1.5 \mathrm{~m}$ above the ground to measure the air temperature; and at the middle of the surface of building envelopes of different materials for measuring the surface temperature

\section{Test Results and Research Analysis}

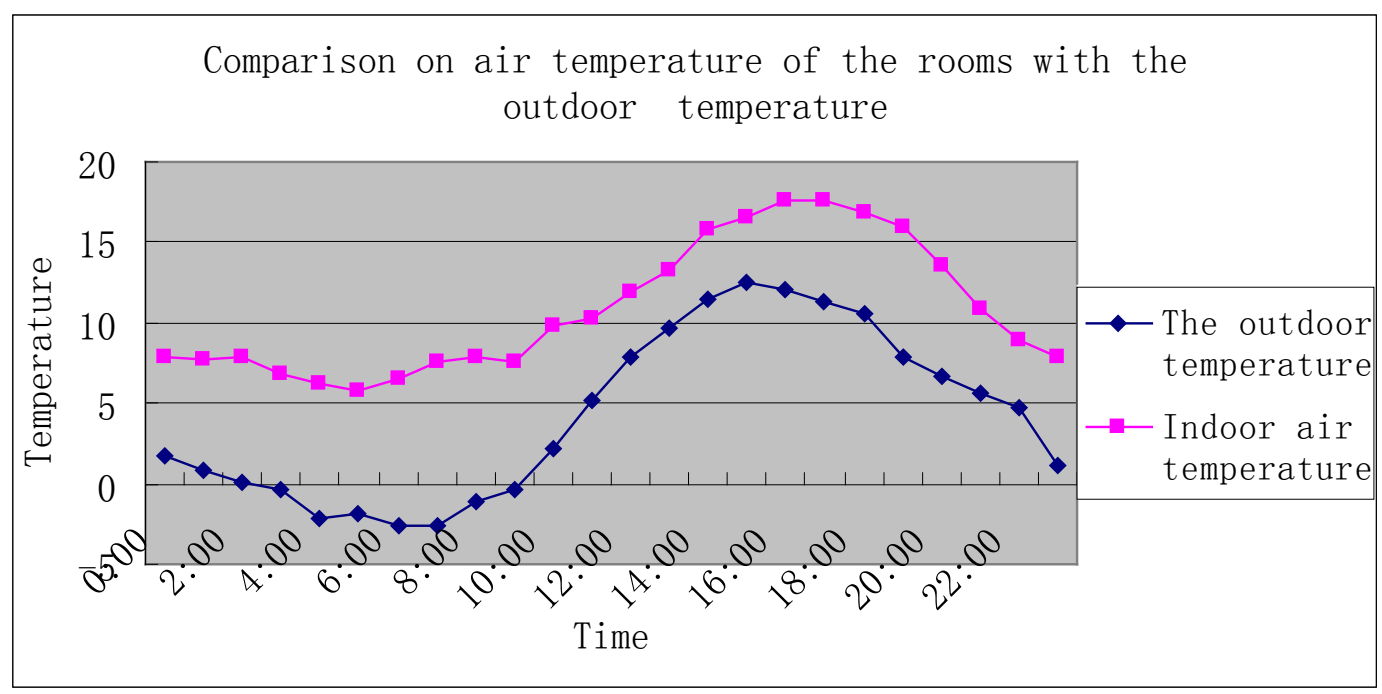


Fig.3 Comparison on air temperature of the rooms with the outdoor temperature

As shown in Fig.3 and Table 1,in the rooms of Naxi nationality stone dwelling ,the outdoor temperature reached the peak of $12.5^{\circ} \mathrm{C}$ at $15: 00$ p.m., while the indoor air temperature arrived at the maximum of $17.6^{\circ} \mathrm{C}$ at $16: 00$ p.m. The maximum of the indoor air temperature is $5.1^{\circ} \mathrm{C}$ higher than one of the outdoor temperature. The minimum of the outdoor temperature was $-2.6^{\circ} \mathrm{C}, 8.4^{\circ} \mathrm{C}$ lower than one of the indoor air temperature which was $5.8^{\circ} \mathrm{C}$. On the day when we carried out the measurement, the fluctuation scope and range of outdoor temperature are from $-2.6{ }^{\circ} \mathrm{C}$ to $12.5^{\circ} \mathrm{C}$, with an amplitude of $15.1{ }^{\circ} \mathrm{C}$, while the indoor air temperature fluctuated from $5.8{ }^{\circ} \mathrm{C}$ to $17.6{ }^{\circ} \mathrm{C}$, with an amplitude of $11.5{ }^{\circ} \mathrm{C}$. It is clear that the fluctuation range of outdoor temperature is much larger than that of indoor air temperature. The thermal insulation performance and thermal stability of stone wall are much better.

Table 1.Comparison of the indoor air temperature with the outdoor temperature

\begin{tabular}{|l|l|l|l|l|}
\hline & \multicolumn{2}{|l|}{$\begin{array}{l}\text { maximum temperature } \\
{\left[{ }^{\circ} \mathrm{C}\right]}\end{array}$} & $\begin{array}{l}\text { minimum temperature } \\
{\left[{ }^{\circ} \mathrm{C}\right]}\end{array}$ \\
\hline The outdoor temperature & 12.5 & -2.6 \\
\hline $\begin{array}{l}\text { Indoor air temperature in the stone } \\
\text { dwellings }\end{array}$ & 17.6 & 5.1 higher & 5.8 & 8.4 higher \\
\hline
\end{tabular}

\section{Conclusion}

It can be concluded from the comparison of the indoor air temperature of Naxi traditional stone dwelling with the outdoor temperature :

[1] The heat-insulation performance and heat stability of stone wall is good; from the aspect of "full life cycle analysis", the stone wall almost has no influence on the environment and saving-energy, so it should be reserved

[2] The maximum of the indoor air temperature is $5.1{ }^{\circ} \mathrm{C}$ higher than one of the outdoor temperature. The minimum of the indoor air temperature is $8.4{ }^{\circ} \mathrm{C}$ higher than one the outdoor temperature.

[3] An amplitude of the indoor air temperature is $3.6{ }^{\circ} \mathrm{C}$ lower than one of the outdoor temperature.

\section{Acknowledgements}

Project Supported by Yunnan Provincial Natural Science Foundation of China: Research on the Sustainable Development in Buildings with Different Geographic and Climate Resources and Environment in Yunnan (2003E0026M)

\section{References}

[1] Design standard for energy efficiency of civil buildings(DBJ53/T-39-2011),in Chinese.

[2] Standard of Climatic Regionalization for Architecture (GB50178-93) ,in Chinese.

[3] Thermal Design Code for Civil Building (GB 50176-93), in Chinese.

[4] Wu Liangyong. Study on Planning for Sustainable Human Settlements in Northwestern Yunnan Province [M]. Yunnan: Yunnan University Press, in Chinese (2000).

[5] [British] Brian Edwards Sustainable Buildings(2 ${ }^{\text {nd }}$ edition) [M]translated by Zhou Yupeng and Song Huahao et al., Beijing: China Architecture and Building Press,2003 